\title{
REDEFINISI ONTOLOGI ASWAJA DALAM PENDIDIKAN MA'ARIF DI ERA KONTEMPORER
}

\author{
Nur Hidayah \\ ISNU (Ikatan Sarjana Nahdlatul Ulama), \\ Jawa Tengah, Indonesia. \\ hidayahnurr15@gmail.com
}

\begin{abstract}
Abstrak
Kajian ini bertujuan untuk mendeskripsikan redefinisi ontologi aswaja dalam pendidikan ma 'arif di era kontemporer. Pendekatan dalam peneltian ini adalah penelitian kepustakaan. Makna Aswaja selalu mengalami pergeseran dari waktu ke waktu. Di sisi lain, konsep aswaja selalu memiliki makna yang berbeda ketika sudah berafiliasi dengan kelompok tertentu. Tak terkecuali, Nahdhatul Ulama sebagai organisasi kemasyarakatan juga memiliki konsep yang khas mengenai aswaja. Hal ini secara langsung berpengaruh pada lembaga-lembaga yang bernaung dibawahnya, seperti halnya Ma'arif. Seiring dengan perkembangan zaman, aswaja NU menjadi semakin ekslusif akibat dari pemahaman para pengikutnya. Banyak kritikan-kritikan dari para tokoh NU kontemporer yang muncul. Definisi aswaja kemungkinan besar akan kembali menjadi ekslusif di kalangan NU. Dari sini diperlukan definisi baru dari sudut pandang lain. Hasil dari kajian ini menyimpulkan bahwa sikap taat dan tunduk pada Allah secara total yang bermuara dari ilmu yang senantiasa diamalkannya adalah definisi baru dari Aswaja ditinjau dari sudut pandang ontologi yang penulis coba tawarkan dalam penulisan ini.
\end{abstract}

Kata kunci: ontologi aswaja, pendidikan ma'arif, kontemporer 
REDEFINITION OF ASWAJA ONTOLOGY IN THE CONTEMPORARY ERA OF MA'ARIF EDUCATION. This study aims to describe the redefinition of aswaja ontology in ma'arif education in the contemporary era. The approach of this study is library research. The meaning of Aswaja has always experienced a shift from time to time. On the other hand, the concept of aswaja has always had a different meaning when it was affiliated with a particular group. No exception, Nahdhatul Ulama as a civic organization also has a distinctive concepts regarding aswaja. It is directly influential on the institutions which take shelter below, as does Ma'arif. Along with the development of the times, aswaja NU are becoming increasingly exclusive as the result of understanding his followers understanding. Much of the criticisms from the contemporary proponents of NU has been appeared. The definition of aswaja will most likely return to being exclusive among NU. Consequently, it takes a new definition from another point of view. The result of this study sum that attitude of obedience and submission to God in total that rises from the science that always be applied is the new definition of Aswaja reviewed from the viewpoint of ontology that the writer tries to offer in this writing.

Keywords: Aswaja ontology, ma'arif education, contemporary

\section{A. Pendahuluan}

Salah satu wacana yang paling menguat dalam pendidikan ma'arif ialah disiapkannya "sekolah/madrasah unggulan aswaja". Krisis karakter bangsa menjadi pemicu utama digiatkannya wacana tersebut. Banyak para tokoh yang berpendapat bangsa ini sedang mengalami degradasi moral dan akhlak. Gubernur Daerah Istimewa Yogyakarta (DIY) Sultan Hamengku Buwono X mengatakan bahwa persoalan utama yang dihadapi bangsa Indonesia adalah masalah kebodohan, kemiskinan, dan krisis akhlak yang belakangan ini begitu memprihatinkan (http://tekno.kompas.com). Wiranto saat membuka Rakernas Gerakan Muda Nurani Rakyat (Gemura) juga mengatakan bahwa Indonesia saat ini sedang mengalami degradasi moral dan akhlak, oleh karena itu harus ada gerakan baru yang sangat peduli pada negeri ini hingga ada kemauan agar tidak kalah dalam persaingan global (http://m.sindonews.com). Hal senada juga diungkapkan oleh Ganjar Pranowo saat membuka Rakerwil LP 
(Lembaga Pendidikan) Ma'arif NU Jawa Tengah mengatakan bahwa keprihatinan saat ini adalah terjadinya krisis karakter kejujuran. Sangat berbahaya jika generasi yang tidak memiliki integritas turut mengurus negara ini. Karena itu, LP Ma'arif juga harus turut memberikan sumbangsih mendidik karakter generasi muda (http://m.republika.co.id). Bahkan Majelis Ulama Indonesia (MUI) telah mendeklarasikan "Gerakan Nasional Perbaikan Akhlak Bangsa”, sebagai bentuk reaksi terhadap maraknya penyimpangan perilaku seksual, kekerasan terhadap anak, pembunuhan dan maraknya narkoba. Menurutnya "Kondisi akhlak bangsa Indonesia saat ini dalam situasi darurat. Hal ini ditandai dengan fakta penurunan moral di berbagai bidang kehidupan (http://m.republika.co.id).

Masalah moral yang dialami Indonesia sebenarnya berujung pada ilmu, hal ini di dalam pendidikan nasional kita, perlahan tapi pasti, ilmu sudah dijauhkan dari amal yang sesungguhnya. Merujuk pada pendapatnya al-Attas, sekarang ini, ilmu sudah dijauhkan, bahkan dihilangkan dari nilai-nilai adab dalam arti luas. Akibatnya, terjadilah suatu keadaan yang disebut oleh al-Attas the loss of adab (hilangnya adab). Efek buruk dari fenomena ini adalah terjadinya kebingungan dan kekeliruan persepsi mengenai ilmu pengetahuan, yang selanjutnya menciptakan ketiadaan adab dari masyarakat. Hasil akhirnya adalah ditandai dengan lahirnya para pemimpin yang bukan saja tidak layak memimpin umat, melainkan juga tidak memiliki akhlak yang luhur dan kapasitas intelektual dan spiritual mencukupi, sehingga, itu semua akan membawa kerusakan di pelbagai sektor kehidupan, baik kerusakan individu, masyarakat, bangsa dan Negara (Husaini, 2013: 187).

Para pemimpin yang tidak layak memimpin dan bahkan tidak bermoral sudah banyak bermunculan di Indonesia. Moral para pemimpin semakin lama semakin buruk, secara langsung hal itu ikut berpengaruh pada kondisi masyarakat. Pemimpin seharusnya mampu menjadi teladan yang baik bagi masyarakat tetapi hal yang terjadi justru malah sebaliknya. Kepercayaan masyakat pada moral pemimpin semakin lama semakin berkurang pasca banyaknya pemimpin yang tidak layak dan tidak bermoral.

Dalam laporan Lingkaran Survei Indonesia pada Juli 2013, menyebutkan bahwa sebesar $51.5 \%$ public tidak percaya bahwa para 
elite politik memiliki komitmen yang kuat untuk melakukan halhal yang baik dalam kebijakan atau perilakunya. Sedangkan sebesar $37.5 \%$ publik percaya komitmen moralitas publik para elite politik. Hasil survey ini berbeda jauh pada survei yang dilakukan oleh LSI pada tahun 2005 dan 2009. Pada tahun 2005, tingkat ketidakperyaan publik pada komitmen para elite politik hanya berkisar pada angka $34.6 \%$, sedangkan pada tahun 2009, tingkat ketidakperyaan publik pada komitmen para elit politik hanya berkisar pada angka 39.6 \% (LSI, 2013). Hasil survey LSI tersebut menunjukkan semakin buruknya moral para pemimpin di Indonesia, hal ini ditandai dengan adanya tingkat kepercayaan publik yang semakin lama semakin menurun.

Ilmu yang telah dijauhkan dari adab memberikan konsekuensi pada lahirnya para pemimpin yang tidak layak dan bahkan tidak bermoral. Ilmu sudah dilepaskan dari nilai (value free). Ilmu seperti pisau yang dapat digunakan untuk berbuat apa saja. Ia bebas seperti burung di udara tanpa terikat sesuatu pun.

Kaitannya dengan ilmu, Imam al-Ghazali, yang dikutip oleh Adian sampai pada kesimpulan "Sesungguhnya kerusakan rakyat terjadi karena kerusakan penguasa dan kerusakan penguasa terjadi karena kerusakan ulama. Andaikan hakim dan ulama tidak rusak, maka akan kecillah kerusakan penguasa disebabkan ketakutan mereka pada hakim dan ulama." (Husaini, 2013: 32).

Quraish Shihab dalam bukunya Wawasan Al-Quran menjelaskan bahwa ulama merupakan orang-orang yang memiliki ilmu dengan sifat dan ciri khas tertentu, sifat yang paling menonjol diantara lain adalah takut kepada Allah sebagaimana ditegaskan dalam firmannya: Sesungguhnya yang takut kepada Allah diantara hambahambanya adalah ulama (QS. Fathir: 28) (Shihab, 2014: 578).

Jadi, dapat dipahami bahwa kerusakan ulama yang dimaksud ialah tidak adanya rasa takut atau tunduk pada Allah swt dalam diri orang-orang yang berilmu. Rasa takut dalam diri orang yang berilmu menjadi suatu keharusan baginya. Sebab, rasa takut yang telah ditanam dalam diri seseorang secara berangsur-angsur lama kelamaan akan mampu mengendalikan seluruh perilakunya. Rasa takut merupakan manifestasi dari iman seseorang yang bermuara 
dari ilmu. Dengan ilmu manusia bisa mengetahui keagungan Allah swt. Rasa kagum, rasa diawasi, rasa takut, dll. akan selalu menjadi pengontrol dalam hidup seseorang. Ilmu menjadi sarana untuk mangantarkan seseorang pada Allah swt bukan sebaliknya.

Oleh karenanya, kutipan dari kesimpulan al-Ghazali di atas jangan difahami secara tekstual. Sebab, jika difahami secara tekstual pernyataan Imam al-Ghazali akan menimbulkan stigma negatif di masyarakat, yang mana semua penyakit atau masalah di dunia ini dianggap sebagai kesalahan dan menjadi tanggung jawab oleh -orang yang disebut- ulama. Kata ulama disitu tidak hanya tertuju pada orang yang disebut kyai atau orang yang faham agama, tetapi kata tersebut juga merujuk pada orang-orang yang berilmu, penguasa berilmu, rakyat berilmu, pejabat berilmu, dan lain-lain. Manusia yang hidup di alam ini tidak ada yang tidak berilmu, walau kapasitasnya berbeda-beda, ada yang sedikit ada pula yang banyak. Sehingga ketika penguasa rusak -dalam arti ia berilmu tetapi tidak ada rasa takut kepada Allah swt- maka yang terjadi adalah rakyat juga ikut rusak, karena pemimpin merupakan panutan bagi rakyat.

\section{B. Pembahasan}

\section{Pendidikan Jalan Perbaikan}

Persoalan moral yang menjadi masalah utama bangsa ini memang sudah seharusnya melibatkan semua kalangan untuk ikut ambil bagian dalam memperbaiki bangsa ini. Para ulama, tokoh, dan seluruh lapisan masyarakat semuanya harus turut serta dalam memperbaiki krisis yang semakin parah ini. Dengan apa? Ya, pendidikan. Semua persoalan tidak pernah lepas dari pendidikan. Hal ini juga ditegaskan oleh Ahmad Tafsir bahwa selama manusia masih menghadapi masalah, selama itu pula ia butuh pendidikan (Tafsir, 2012: 39).

Meski demikian, perlu dicatat pula bahwa melalui pendidikan masalah selalu muncul. Sebab, pendidikan merupakan sumber masalah sekaligus untuk menyelesaikan masalah. Para pemimpin korup misalnya, jangan dikira dia tidak mengenyam pendidikan, justru mereka umumnya sudah mengenyam pendidikan yang tinggi. Hal ini juga diungkapkan oleh Ketua PP LP Ma'arif NU Zainal 
Arifin Junaidi saat halaqah pendidikan yang diselenggarakan PC LP Ma'arif NU Kudus di Aula MA NU Banat Kudus. Ia mengatakan; "Pendidikan nasional belum mampu menghasilkan negarawan dan pemimpin berintegritas. Buktinya, hingga tahun 2013 pendidikan Indonesia telah menghasilkan ribuan koruptor. Indonesia adalah negara yang tingkat korupsinya terbesar nomor dua di dunia dengan para pelakunya adalah orang-orang terdidik. Tidak ada yang korupsi itu tamatan SMP atau SMA, semuanya sarjana. Mahfud MD (mantan ketua Mahkamah Konstitusi-red) bilang 16 dari 33 gubernur di Indonesia terkena kasus korupsi” (http://m.nu.or.id).

Moral para elit publik yang semakin lama semakin menurun ternyata merupakan buah dari pendidikan nasional. Pendidikan nasional belum mampu menghasilkan pemimpin yang berintegritas. Arifin juga menambahkan bahwa "menurut data BPS pada semester pendidikan juga menghasilkan tujuh juta pengangguran terdidik. Bahkan menurut Human Development Index, pendidikan nasional telah mengantarkan daya saing sumber daya manusia (SDM) bangsa Indonesia berada pada peringkat 124 . Artinya, pendidikan kita tidak menghasilkan SDM yang tidak kompetitif, tidak memiliki daya saing dan tidak siap berkompetisi dengan negara tetangga. Indonesia itu masih kalah dengan singapura, Malaysia maupun Brunei Darussalam.” (http://m.nu.or.id).

Pendidikan memang sumber masalah sekaligus sumber penyelesai masalah. Orang baik yang ingin memperbaiki bangsanya sudah pasti melalui pendidikan, orang jahat yang ingin merusak negaranya juga melalui pendidikan. Memang benar, pendidikan merupakan masalah yang tidak pernah selesai. Semua memiliki kepentingan dengan pendidikan, entah itu kepentingan baik atau buruk, yang pasti semuanya butuh pendidikan. Mengapa sedemikian kompleksnya hasil dari pendidikan? Kenapa tidak yang baik saja hasil dari pendidikan?

Dalam hal ini, Ahmad Tafsir menjelaskan makna pendidikan sebagai berikut:

"Pendidikan adalah usaha menolong manusia menjadi manusia. Menurutnya, Ada dua aspek dalam pendidikan, yaitu menolong dan manusia. Mengapa menolong, bukan mencetak atau mewujudkan? Ya, karena pendidik tahu bahwa setiap manusia memiliki potensi yang dapat dikembangkan untuk menjadi manusia. Pada setiap 
manusia itu ada potensi untuk menjadi manusia, ada juga potensi untuk menjadi bukan manusia, binatang misalnya. Teori inilah yang dapat menjelaskan mengapa orang yang dididik itu ada juga yang gagal menjadi manusia. Misalnya korupsi (ini bukan sifat manusia). Kata menolong juga menegaskan bahwa perbuatan mendidik itu hanya sekedar menolong. Jadi, pendidik jauh sebelum berbuat telah mengetahui bahwa muridnya nanti ada yang berhasil dan ada yang tidak." (Tafsir, 2012: 33-39).

Oleh karenanya, wajar kalau pendidikan merupakan sumber masalah dan sekaligus sumber penyelesai masalah, karena pendidikan sendiri hanyalah perbuatan menolong -pada sesuatu yang baik- bukan mencetak apalagi mewujudkan.

\section{Respon Pendidikan Ma'arif}

Persoalan moral dan akhlak yang saat ini statusnya sedang krisis di negara ini, ternyata sudah menjadi suatu keharusan bagi semua lapisan di masyarakat bawah, menengah, dan atas untuk turut serta memperbaikinya. Tak terkecuali, Ma'arif yang notabene sebagai lembaga pendidikan di bawah organisasi masyarakat keagamaan (Nahdhatul Ulama) juga memiliki hak untuk itu. Harus diakui pula bahwa itu juga merupakan respon dari ditetapkannya kurikulum 2013, yang esensinya adalah pendidikan karakter. Meski tujuannya sama, tetapi dalam pelaksanaanya semua lembaga pendidikan memiliki gaya dan khas masing-masing, termasuk Lembaga Pendidikan Ma'arif. Dalam hal ini, Ma'arif menyiapkan sekolah unggulan berbasis aswaja sebagai bentuk keseriusan dalam melaksanakan kurikulum 2013.

Penyiapan madrasah/sekolah unggul yang berbasis Ahlussunnah Wal-Jama'ah semakin menguat pasca ditetapkannya beberapa keputusan yang dihasilkan dari rapat pleno Pengurus Pusat LP Maarif NU. Dalam rapat pleno tersebut, menghasilkan 9 program Prioritas di 2014. Yaitu; (1) implementasi peraturan pelaksanaan program pendidikan NU (Hasil Rakernas); (2) Pembangunan sistem pendataan satuan pendidikan dengan web based system; (3) Penataan status satuan pendidikan yang didirikan lembaga/jam'iyah dengan memfungsikan badan hukum NU untuk satuan pendidikan yang didirikan lembaga/jam'iyyah; (4) Penerapan standar pendidikan Ma'arif NU dan pembangunan sistem penjaminan mutu; (5) revitalisasi kurikulum Aswaja dan Ke-NU-an; (6) kaderisasi Aswaja 
di lingkungan siswa dan PTK; (7) Peranserta dalam implementasi Kurikulum 2013 dan program Pendidikan Menengah Universal (PMU); (8) Penguatan kajian, penelitian dan publikasi bidang pendidikan oleh dan untuk lembaga; dan (9) Penguatan jaringan kerjasama dengan lembaga pemerintah maupun swasta di berbagai bidang bantuan beasiswa untuk siswa dan PTK, penguatan lembaga dan SDM pendidikan, penempatan kerja lulusan pendidikan kejuruan, dan lain-lain (http://maarif-nu.or.id).

Perbaikan pendidikan di Ma'arif terus dilakukan demi tercapainya tujuan pendidikan. Penerapan standar pendidikan dan sistem penjaminan mengisyaratkan suatu bentuk keseriusan Ma'arif dalam pelaksanaan pendidikan karakter pada kurikulum 2013. Sebab, secara keseluruhan kegiatan-kegiatan yang dikembangkan oleh Ma'arif selama 2013, aspek penjaminan mutu pendidikan terlihat belum banyak dilakukan karena berbagai keterbasan yang ada, baik sumber dana, manajemen dan SDM yang dimiliki oleh LP Ma'arif NU (http://maarif-nu.or.id).

Sementara revitalisasi kurikulum aswaja dan ke-NU-an menjadi sesuatu yang paling pokok dan utama dalam hasil rapat tersebut. Revitalisasi aswaja merupakan konsekuensi dan bentuk keseriusan Ma'arif dalam menyiapkan madrasah/sekolah unggulan berbasis aswaja. Sekolah/madrasah unggulan berbasis aswaja terus dikembangkan dalam rangka turut serta membangun generasi yang berkualitas dan berakhlak mulia.

\section{Madrasah Berbasis Ahlussunnah Wal-Jama'ah}

Madrasah unggulan berbasis aswaja terus dikembangkan oleh Ma'arif dengan berbagai cara dan tentunya berdasarkan pijakan pandangan kaum Nahdhiyin tentang makna aswaja. Aswaja sampai saat ini masih terus dikaitkan dengan hadits Maa Ana 'Alaihi wa Ashhaabi. Kiai Abdul Muchith Muzadi menjelaskan Maa Ana 'Alaihi wa Ash-haabi sebagai berikut:

"Kiranya tidak meleset dari kebenaran, kalau Maa Ana 'Alaihi Wa Ash-haabi, dijelaskan dengan kata-kata: ajaran (wahyu Allah swt) yang aku sampaikan kepada sahabatku dan aku amalkan bersama mereka. Dengan kata lain, Maa Ana 'Alaihi Wa Ash-haabi ajaran Islam yang paling murni, otentik, baku, dan standart. Dengan pemikiran, semua kaum Muslimin di zaman Rasulullah saw bersama sahabat 
adalah penganut Ahlussunnah Wal-Jama'ah yang tidak masuk neraka (Muzadi, 2006: 146).

Makna aswaja -khususnya di Nahdhatul Ulama- pada perkembangannya menjadi sempit dan ekslusif. Aswaja sudah dianggap sebagai kelompok, aliran, ataupun sekte. Banyaknya kelompok-kelompok Islam yang terus bermunculan membuat NU untuk merumuskan sendiri konsep aswaja. Diantaranya Kiai Bisri Mustofa, menurutnya aswaja adalah paham yang menganut ajaran dari salah satu empat madzhab di bidang fiqih Di bidang tauhid, menganut ajaran Imam Abu Hasan al-Asy'ari dan Imam Abu Mansur al-Maturidi. Di bidang tasawuf menganut dasar-dasar ajaran Imam Qasim al-Junaidi (Zuhri, 2010: 240).

Definisi aswaja Kiai Bisri pada dasarnya merupakan Manhaj Fikrah Nahdhiyah (metode berpikir ke-NU-an) yang digunakan oleh Nahdhatul Ulama dalam merespon persoalan kegamaan maupun kemasyarakatan dengan ciri-ciri tawassut (moderat), tasamuh (toleran), Ishlahiyah (perbaikan), tathawwuniyah (dinamis), dan manhajiyah (metodologis) (Navis, 2012: 169). Iman, Islam dan Ihsan sebagai wujud dari entitas dalam Islam yang digambarkan oleh Kiai Bisri, sebenarnya hanyalah suatu bentuk arahan dan anjuran bagi warga Nahdhiyin agar lebih mudah dalam melaksanakan ajaran agama. Namun, karena pemahaman masyarakat tidak semuanya bisa memahami dengan baik, pada akhirnya aswaja menurut NU menjadi sangat ekslusif. Dampaknya, aswaja ala NU sudah menjadi suatu aliran, kelompok ataupun sekte dengan sebuah madzhab. Hakikat (ontologi) aswaja sudah bergeser ke wilayah epistemologi, padahal keduanya merupakan sesuatu yang sangat berbeda.

Pemaknaan hadits secara tekstual akan terus memunculkan kelompok-kelompok yang mengklaim dirinya Ahlussunnah WalJamaa'ah, bahkan NU sendiri juga mengklaim dirinya Ahlussunnah Wal-Jama'ah (Zuhri, 2010: 109). Dengan konsep yang dimilikinya, NU berusaha membedakan dirinya (aswaja) dengan kelompokkelompok lain yang mengaku aswaja. Jika seperti ini, apakah mungkin sikap tawassut, tasamuh, dan tawazun dapat terwujud? Perpecahan umat Islam memang terjadi karena perilaku umat Islam yang radikal; seperti suka mengkafirkan, membid'ahkan, menyesatkan, identik 
dengan kekerasan, dan lain-lain. Namun, perlu kiranya diketahui bahwa hal itu timbul dari suatu pemikiran dan keyakinan seseorang. Pemikiran yang begitu ekstrim dan fanatik akan mampu memicu konflik pada umat Islam. Walhasil, perpecahan terjadi. Mengapa NU tidak menjadi perekat antar kelompok dan golongan umat Islam lainnya berdasarkan faham Aswaja? Pendekatan menuju Islam Ahlussunnah Wal-Jama'ah boleh saja berbeda dengan kelompok lain, tetapi alangkah baiknya jika definisi aswaja yang digunakan oleh NU seharusnya mampu menjadi pemersatu umat Islam, bukan sebaliknya.

Madrasah unggulan berbasis Ahlussunnah Wal-Jama'ah yang akhir-akhir ini sedang marak di bicarakan di berbagai media sosial, terutama di internal NU, sebagai bentuk kontribusinya dalam membangun generasi yang berkualitas dan berakhlak mulia -yang pasti dengan ciri utamanya tawassut, tasamuh, dan tawazunseakan sedikit harapannya dapat terwujud jika definisi aswaja sebagai suatu aliran masih saja berlaku di masyarakat, khususnya warga Nahdhiyin. Sebab, jika definisi aswaja -yang sudah bergeser ke wilayah epistemologi- masih berlaku di kalangan Nahdhiyin khususnya, dan masyrakat umumya. Hal itu sama saja mengajarkan pada peserta didik sejak dini untuk menjadi orang yang fanatik dan ekslusif. Kecil harapannya sikap tawassut, tasamuh, dan tawazun yang menjadi ciri utama aswaja NU dapat terwujud, jika pemahaman warga Nahdhiyin khusunya, mengenai aswaja masih tetap diartikan sebagai sebuah madzhab.

Belakangan ini, definisi aswaja sebagai sebuah madzhab atau aliran keagamaan sebenarnya sudah mendapat banyak kritik dari para tokoh NU. Said Aqil Siradj merupakan salah satu dari tokoh yang menggugat konsep aswaja sebagai sebuah madzhab. Menurutnya, aswaja adalah metode berfikir keagamaan yang mencakup segala aspek kehidupan dan berdiri diatas prinsip keseimbangan, jalan tengah, dan netral dalam akidah, penengah dan perekat dalam kehidupan sosial kemasyarakatan, serta keadilan dan toleransi dalam berpolitik. Sehingga aswaja dapat menjadi perekat antar kelompok dan golongan, menjadi tasamuh, toleran dengan non-aswaja, dan non muslim sekalipun. Ini merupakan sebuah konsep aswaja yang mencari jalan tengah antara nash dan akal, antara ra'yi dan naqal. 
Jalan beberapa ulama, tidak hanya pengikut Asy'ari -yang sunni (http://m.nu.or.id).

Konsep aswaja yang ditawarkan oleh Said Aqil Siradj sebagai metode berfikir, mengisyaratkan bahwa aswaja bukan mutlak dimiliki golongan tertentu. Oleh karenanya, dapat dipahami bahwa konsep aswaja tersebut dapat mencakup berbagai aliran yang mengklaim diri mereka aswaja, bahkan non-aswaja sekalipun. Said Aqil juga mengatakan kalau NU mampu mengayomi seluruh aliran yang ada di Indonesia ini -yang penting tidak keluar dari tauhid, Alquran, iman kepada hari kiamat, maka NU bisa menjadi muara dari segala aliran (http://m.nu.or.id).

Seperti yang telah dijelaskan sebelumnya, konsep tersebut masih berada dalam wilayah epistemologi. Meski hal itu bisa dijadikan sebagai perekat antar kelompok dan golongan bahkan pemersatu umat, baik muslim maupun non-muslim. Konsep tersebut lebih tepat kiranya dikatakan hanya tertuju khusus bagi para pemimpin umat (ulama, mujtahid, dan ahli hukum). Para pemimpin mungkin dan bahkan pasti mempunyai metode-metode berfikir dalam melangkah di kehidupan ini berdasarkan pedoman dasar agamanya, yaitu Alquran dan Hadis, karena kapasitas keilmuannya sudah barang tentu melebihi para pengikutnya (rakyat). Lalu bagaimana dengan orang awam? Umumnya orang awam muslim memang samina (mendengar) wa atha'na (taat) -walau mungkin terkadang hanya sami'na saja- kepada pemimpin atau kyainya. Selain itu, perlu diakui juga bahwa banyak pula yang tidak seperti itu -samina wa atha'na-. Oleh karenanya, gesekan-gesekan kecil maupun besar antara NU dengan kelompok lain kemungkinan besar dapat terjadi di kedepannya. Hal ini cukup logis mengingat orang awam belum tentu memiliki metode berfikir yang benar. Sehingga pengkristalan makna aswaja sebagai madzhab tertentu diperkirakan akan senantiasa berlaku dikalangan umum.

Dari sini, dibutuhkan suatu definisi baru dari sudut pandang lain dengan tanpa mengubah, mengganti dan bahkan mengacakacak dari definisi para ulama sebelumnya. Tetapi, definisi yang baru ini mencoba mencari hakikat dan universalitas makna aswaja, tanpa terikat oleh situasi dan kondisi apapun, tetapi mencakup dan selalu sesuai dengan situasi dan kondisi dimanapun berada. 
Nur Hidayah

\section{Redefinisi Aswaja}

Mendefinisikan aswaja dari sudut pandang apapun akan lebih elok jika dimulai dari hadis Rasulullah saw, tentang perpecahan umat; yang artinya:

"Akan terpecah umatku (umat Islam) menjadi 73 sekte. Yang selamat daripadanya satu dan yang lainnya binasa. Nabi ditanya: siapa yang yang selamat? Nabi menjawab: Ahlussunnah Wal-Jama'ah. Apa Ahlussunnah Wal-Jama'ah? Nabi menjawab: yang aku sekarang ini dan para sahabatku" (al Syahrastani, tt: 3).

An-Najiyah, Ahlussunnnah Wal-Jama'ah, dan Maa Ana 'Alaihi al-yaum wa Ash-habi, ketiganya merupakan kalimat yang menjadi esensi dari hadis tersebut, ketiganya memiliki hubungan yang sangat kuat, melalui ketiganya pula kita bisa mengetahui hakikat aswaja yang sebenarnya. Oleh karenanya, dalam hal ini ketiga kata tersebut akan di bahas satu persatu agar bisa mengungkap hakikat aswaja yang sesungguhnya.

a. An-Najiyah (Orang yang Selamat)

Buku Polaritas Sektarian yang disusun oleh Purna Siswa Aliyah 2007, Madrasah Hidayatul Mubtadi-ien Lirboyo Kediri, menjelaskan makna hadis tersebut sebagai berikut:

"Secara tekstual, hadits tersebut memang menyebutkan jumlah firqah yang mana semuanya akan masuk neraka, kecuali satu. Tetapi, sesungguhnya jumlah firqah yang disebutkan oleh Rasulullah tidaklah untuk menjelaskan bahwa semua golongan akan masuk neraka. Tetapi, untuk menjelaskan, begitu banyaknya jalan menuju kesesatan, dan hanya ada satu jalan menuju kebenaran" (Lirboyo Press, 2007: 7).

Penjelasan tersebut dapat dipahami bahwa kata firqah yang tertuang dalam hadits tersebut esensinya adalah jalan. Hal ini sangat masuk akal, mengingat tidak ada kelompok yang tidak memiliki jalan untuk menggapai tujuannya. Dari semua jalan yang ada hanya satu yang selamat. Sangat rasional pula ketika Nabi saw, bersabda hanya satu kelompok (jalan) yang selamat. Sebab, tidak mungkin seseorang berjalan di dua jalan untuk pergi ke tujuannya pada waktu bersamaan. Tetapi, bukan berarti hanya ada satu jalan menuju kebenaran. Banyak jalan yang bisa mengantarkan seseorang pada tujuannya dengan selamat. Tetapi bukan berarti hanya ada satu jalan menuju kebenaran. Oleh karena itu, selamat adalah jalan yang benar, bukan 
jalan itu sendiri. Jalan yang benar belum tentu selamat, sedangkan selamat sudah tentu melalui jalan yang benar. Dua orang pergi ke satu tujuan dengan jalan yang berbeda belum tentu keduanya selamat sampai tujuan secara bersamaan. Sebab, esensi dari selamat adalah sampai pada tujuan dengan keadaan baik segalanya, bukan jalan yang dianggap benar.

Demikian, dapat dipahami pula mengenai uraian Kiai Bishri yang mengikuti madzhab meski diklaim sebagai jalan yang paling benar, tetapi belum tentu penggunanya bisa selamat sampai pada tujuan. Sebab, esensi dari selamat adalah sampai pada tujuan dengan keadaan baik segalanya, bukan jalan yang dianggap benar.

b. Ahlussunnah Wal-Jama’ah

Ketika Nabi saw, ditanya siapa yang selamat? Nabi menjawab; Ahlussunnah Wal-Jama’ah. Secara kebahasaan Ahlus Sunnah WalJama'ah adalah istilah yang tersusun dari tiga kata.yaitu:

1) $\mathrm{Ahl}$

Secara linguistik, kata ahli berasal dari kata ahala, ya'halu, atau ya'hilu, uhulan. Kata ini mempunyai varian makna seperti penghuni sebuah tempat, suami, istri, kerabat, dan bisa juga bermakna pengikut (Lirboyo Press, 2007: 7).

2) Al-Sunnah

Sunnah secara harfiah berarti suatu sarana, suatu jalan, aturan, dan cara untuk berbuat atau cara untuk hidup. Ia juga berarti metode atau contoh. Dalam arti aslinya, sunnah menunjuk pada perkataan, perbuatan dan persetujuan yang berasal dari Nabi Saw (Alim, 2011: 188). Sunnah bermakna pula al-thariqah wa law ghaira mardhiyah (jalan atau cara walaupun tidak diridhai). Sedangkan secara terminologis, "Sunnah" adalah suatu nama untuk cara yang diridhai dalam agama, yang telah ditempuh oleh Rasulullah saw, atau selainnya dari kalangan orang yang mengerti tentang Islam, seperti para sahabat Rasulullah Saw (Navis, 2012: 2).

Imam Ibnu Rajab al-Hanbal mengatakan:

"Yang dimaksud kata sunnah oleh para ulama yang menjadi panutan adalah jalan yang ditempuh oleh Nabi saw, dan para sahabatnya yang selamat dari keserupaan dan syahwat" (Ramli, 2011: 54).

Dari sini, perlu kiranya diperhatikan dua kalimat inti dari 
definisi As-Sunnah, yakni "jalan yang ditempuh oleh Nabi saw" dan "diridhai oleh agama (selamat)". Istilah yang pertama mengisyaratkan apa yang telah diketahui Nabi saw, telah dikerjakan. Lebih mudahnya, jalan ibarat ilmu, sedang kata ditempuh memiliki kesamaan dengan kata berjalan, hal itu ibarat amal. Apa yang dilakukan oleh Nabi saw sebenarnya -baik perkataan, perbuatan, maupun persetujuan-, merupakan amalan yang didasarkan pada ilmu dan bersumber dari wahyu. Wahyu merupakan sumber dari semua ilmu Nabi saw, baik wahyu Qauli (Alquran) maupun wahyu Kauni (alam semesta).

Sedangkan kalimat yang kedua merupakan penegas dari yang pertama bahwa semua yang dilakukan oleh Nabi saw, diridhai oleh Allah swt dalam arti apa yang dilakukan oleh Nabi berada di jalur yang selamat, yaitu jalan benar. Selamat dalam bahasa arabnya adalah salima. Dari asal kata itu dibentuk kata aslama, yuslimu, islaman, yang berarti memeliharakan dalam keadaan selamat sentosa, dan berarti juga menyerahkan diri, tunduk, patuh dan taat. Seseorang yang bersikap demikian dinamakan Muslim, yaitu orang yang telah menyatakan dirinya taat, menyerahkan diri, patuh, dan tunduk kepada Allah (Alim, 2011: 91). Ini berarti hakikat bagi orang-orang yang selamat adalah orang-orang yang taat kepada Allah swt, dan ketaatan tersebut didasarkan atas ilmu -yang bersumber dari wahyuyang senatiasa dimalkan. Oleh karenanya, dapat dipahami bahwa As-Sunnah merupakan ajaran Nabi saw, yang bersifat integral antara ilmu dengan amal, sehingga hal itu bisa menambah rasa tunduknya pada Allah swt.

3) Al-Jama'ah

Al-Jama'ah berasal dari kata jama'ah artinya mengumpulkan sesuatu, dengan mendekatkan sebagian ke sebagian lain. Kata "Jama'ah" juga berasal dari kata ijtima' (perkumpulan), yang merupakan lawan kata dari tafarruq (perceraian) dan juga lawan dari kata furqah (perpecahan). Jama'ah adalah sekelompok orang banyak; dan dikatakan juga sekelompok manusia yang berkumpul berdasarkan satu tujuan. Selain itu, jama'ah juga berarti kaum yang bersepakat dalam suatu masalah. Secara terminologis al-Jama'ah adalah kelompok kaum muslimin dari para pendahulu dari kalangan sahabat, tabi'in dan orang-orang yang mengikuti jejak kebaikan mereka sampai hari kiamat. Mereka berkumpul berdasarkan 
Alquran dan As-Sunnah, dan mereka berjalan sesuai dengan yang telah ditempuh oleh Rasulullah Saw. baik secara lahir maupun batin (Navis, 2012: 4).

Jama'ah ini merupakan kelompok mayoritas, pada mereka terdapat ilmu, hikmah, akal, kebijakssanaan, khilafah, kepemimpinan, pemerintahan, dan politik. Merekalah yang mengatur pelaksanaan shalat jumat, majlis pertemuan, shalat jama'ah, mengatur masjid, mengatur pelaksanaan ibadah haji, hari raya, dan jihad. Mereka juga mengatur moneter negara, baik pemasukan dan pengeluaran, menjaga benteng pertahanan dan beberapa kantor. Mereka adalah orang yang selalu berjihad di jalan Allah sekaligus sebagai pengikut setia rasul. Cengkrama mereka tentang zuhud. Setiap hembus nafas mereka selalu terjaga. Setiap zaman mereka selalu menjadi tauladan. Petuah mereka sebagai pencegah. Ajakan mereka adalah akhirat (selamat). Kehidupan mereka sebagai kaca benggala. Kematian mereka menjadi ibrah. Kubur mereka menjadi tempat ziarah. Tapak tilas mereka tidak pernah lekang oleh waktu. Selamanya mereka tidak akan pernah dilupakan. Dan semua hati mencintai mereka (Lirboyo Press, 2007: 19). Ini berarti, kata al-Jama'ah yang dimaksud bukanlah kelompok ataupun aliran. melainkan Jama'ah yang dimaksud disini ialah orangorang yang telah mengamalkan ilmunya, dengan tujuan agar selamat fid-dunya wal akhirat. Amalan tersebut tidak hanya beorientasi pada hal-hal ukhrawi, tetapi berorientasi pula pada hal-hal yang duniawi (profan), semuanya bersifat terpadu dengan hanya satu tujuan, yakni selamat dalam arti tunduk pada Allah.

Dari uraian diatas, dapat diambil kesimpulan bahwa aswaja bukanlah kelompok, golongan, aliran, sekte apalagi dipahami hanya sebagai jalan yang benar. Tetapi, aswaja merupakan orang-orang yang tunduk pada Allah swt, yang bermuara dari ilmu dan amalnya.

c. $\quad M \bar{a} A \bar{n}$ 'Alaihi Al-Yaum Wa Aș-ḥābi

Banyak para ulama yang sudah menafsirkan kalimat ini, dan semuanya memiliki substansi yang sama, walau berbeda redaksinya. Diantaranya Kiai Abdul Muchith Muzadi menjelaskan Maa Ana 'Alaihi Wa Ash-haabi sebagai berikut:

"Kiranya tidak meleset dari kebenaran, kalau Maa Ana 'Alaihi Wa Ashhaabi, dijelaskan dengan kata-kata: ajaran (wahyu Allah swt) yang aku sampaikan kepada sahabatku dan aku amalkan bersama mereka. Dengan 
Nur Hidayah

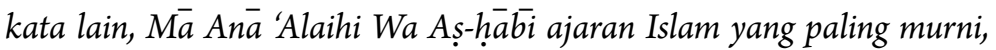
otentik, baku, dan standart. Dengan pemikiran, semua kaum Muslimin di zaman Rasulullah saw bersama sahabat adalah penganut Ahlussunnah Wal-Jamäah yang tidak masuk neraka" (Muzadi, 2006: 146).

Penjelasan serupa juga dikatakan oleh Masyhudi Muchtar, menurutnya:

"Ahlussunnah Wal-Jamāah adalah ajaran (wahyu Allah swt) disampaikan kepada sahabat-sahabatnya dan aku amalkan bersama mereka."(Muchtar, 2007: 3).

Substansi dari penjelasan tersebut mengenai $M \bar{a} A \bar{n}$ 'Alaihi Wa Aṣ-ḥabi pada dasarnya hanyalah pada ilmu dan amal sebagaimana yang telah dijelaskan dalam sub-bab Ahlussunnah Wal-Jamäah sebelumnya. Jawaban Nabi mengenai pertanyaan Ahlussunnah Wal-Jama'ah sebenarnya merupakan suatu bentuk perintah dan penegasan beliau bagi umat Islam untuk mengikuti Nabi saw, agar bisa selamat pada tujuannya. Nur Uhbiyati dalam bukunya DasarDasar Ilmu Pendidikan Islam menjelaskan ada tiga faktor mengapa harus mengikuti Nabi Saw:

a. Nabi Muhammad saw, sebagai utusan Tuhan, merupakan orang yang paling tahu tentang agama yang dibawanya (Islam), dan paling sempurna dalam hal mengamalkan ajaran-ajaran agama Islam.

b. Seorang Islam selain diharuskan taat kepada Allah, juga harus patuh dan mengikuti jejak langkah orang yang menjadi Nabi saw, dan utusan-Nya, yaitu Nabi Muhammad (QS. An-Nisa': 59, QS. Al-Anfal: 20).

c. Dalam kenyataannya pribadi Nabi Muhammad saw, adalah sangat mulia dan disebut insan kamil artinya manusia sempurna. Kesempurnaan ini tidak terjadi sjak masa kenabian, tetapi semenjak beliau belum diutus menjadi Nabi saw (Uhbiyati, 2013: 27).

Berbagai uraian diatas dapat ditarik kesimpulan bahwa Ahlussunnah Wal-Jamä'ah bukanlah aliran maupun kelompok. Tetapi Ahlussunnah Wal-Jamäahadalah orang-orang yang tunduk pada Allah swt. yang bermuara dari ilmu dan amalnya. 
Redefinisi Ontologi Aswaja dalam Pendidikan Ma'arif di Era kontemporer

\section{Simpulan}

Istilah aswaja selalu memiliki makna sesuai dengan perkembangan zaman, sampai sekarang makna aswaja masih diyakini sebagai kelompok dan aliran yang selamat. Disaaat krisis moral seperti ini, keyakinan seperti itu sudah dijadikan ideologi bagi masingmasing organisasi untuk mengklaim dirinya sebagai kelompok dan aliran yang paling selamat. Tak terkecuali, lembaga pendidikan di bawah organisasi yang mengklaim dirinya sebagai aliran Ahlussunnah Wal-Jama'ah juga turut serta mengklaim lembaganya berhaluan Ahlussunnah Wal-Jama'ah. Keyakinan seperti ini hanya akan menimbulkan pernyataan sesat menyesatkan antara tokoh agama satu dengan yang lainnya. Hal ini pula yang bisa menimbulkan perpecahan dalam Islam semakin parah, dan sulit disatukan. Keyakinan seperti ini juga bisa melahirkan bibit-bibit muda yang fanatik ketika hal itu diterapkan pada lembaga pendidikannya. Sulit kiranya masalah moral bisa di minimalisir jika ideologi pendidikannya masih seperti itu.

Ma'arif sebagai lembaga pendidikan di bawah organisasi Nahdhatul Ulama sudah seharusnya menjadi contoh bagi organisasi yang lain. Madrasah unggulan yang disiapkan oleh Ma'arif sudah seharusnya merumuskan kembali ideologi aswaja masa lalu, yang bisa menimbulkan pemahaman yang ekslusif. Penafsiran dari sudut pandang lain diperlukan agar sikap fanatik yang dikahawatirkan tidak akan lahir pada generasi muda. Aswaja merupakan sikap taat dan tunduk pada Allah secara total. Sikap tersebut bermuara dari ilmu yang senantiasa diamalkannya. Baik amal yang berifat ukhrawi; seperti shalat, puasa, zakat, maupun amal yang bersifat duniawi, dalam arti bermanfaat untuk manusia; seperti hape, motor, mobil, mesin penggiling, dan lain-lain. Dalam bahasa sekarang amal duniawi lebih familiar dengan sebutan teknologi. Kedua amal tersebut sudah seharusnya menimbulkan rasa semakin patuhnya terhadap Allah swt, bukan malah sebaliknya. Hakikat aswaja yang demikianlah yang sudah seharusnya diterapkan sebagai ideologi suatu organisasi apalagi suatu lembaga pendidikan. Agar mampu menghasilkan pendidikan yang lebih berkualitas. 
Nur Hidayah

\section{DAFTAR PUSTAKA}

Alim, Muhammad. 2011. Pendidikan Agama Islam. Bandung: Rosda.

Husaini, Adian. et. al. 2013. Filsafat Ilmu, Perspektif Barat dan Islam. Jakarta: Gema Insani.

Lingkaran Survei Indonesia, 2013. Moralitas Publik Para Elite Di Titik Nadir. Juli.

Muchtar, Masyhudi. dkk, 2007. Aswaja An-Nahdhiyah. Surabaya: Khalista.

Muhammad Bin Abdul Karim Al Syahrastani, Muhammad Bin Abdul Karim. tt. Al-Milal wa Al-Nihal. Diterjemahkan oleh Asywadie Syukur. Surabaya: Bina Ilmu.

Muzadi, Abdul Muchith. 2006. NU Dalam Perspektif Sejarah \& Ajaran (Refleksi 65 Th. Ikut NU). Surabaya: Khalista.

Navis, Abdurrahman. dkk, 2012. Risalah Ahlussunnah Wal-Jama'ah, Dari Pembiasaan Menuju Pemahaman dan Pembelaan Akidah Amaliah NU. Surabaya: Khalista.

Purna Siswa Aliyah 2007 Madrasah Hidayatul Mubtadi-ien. Polaritas Sektarian, Rekonstruksi Doktrin Pinggiran. Kediri: Lirboyo Press.

Ramli, Muhammad Idrus. 2011. Pengantar sejarah Ahlussunnah WalJama'ah. Surabaya: Khalista.

Shihab, Quraish. 2013. Wawasan Al-Quran. Tafsir Tematik Atas Pelbagai Persoalan Umat. Bandung: Mizan.

Tafsir, Ahmad. 2012. Filsafat Pendidikan Islam, Integrasi Jasmani, Rohani, dan Kalbu, Memanusiakan Manusia. Bandung: Rosda.

Uhbiyati, Nur. 2013. Dasar-Dasar Ilmu Pendidikan Islam. Semarang: Pustaka Rizki Putera.

Zuhri, Achmad Muhibbin. 2010. Pemikiran KH. M. Hasyim Asy'ari Tentang Ahl al-Sunnah Wa al-Jama'ah. Surabaya: Khalista.

http://m.nu.or.id/a,public-m,dinamic-s,detail-ids,1-id,166-lang,idc,warta-t,Rekonstruksi+Aswaja-.phpx. 
Redefinisi Ontologi Aswaja dalam Pendidikan Ma'arif di Era kontemporer

http://m.nu.or.id/a,public-m,dinamic-s,detail-ids,44-id,49686-lang,idc,nasional-t,LP+Maarif+Jateng+Siapkan+Sekolah+Unggulan+ Aswaja-.phpx

http://m.nu.or.id/a,public-m,dinamic-s,detail-ids,44-id,52025-lang,idc,nasional-t,Pendidikan+Nasional+Belum+Hasilkan+Pemimpi $\mathrm{n}+$ Berintegritas-.phpx

http://m.republika.co.id/berita/nasional/umum/14/05/13/n5i85amui-deklarasikan-gerakan-perbaikan-akhlak-bangsa

http://m.sindonews.com/read/2012/10/30/12/684086/wirantoindonesia-mengalami-degradasi-moral-akhlak

htt p : / / m . s u a r a merdeka.com / index.php/ read / cetak/2014/01/28/250785

http://tekno.kompas.com/read/2009/02/10/18331085/krisis.akhlak. di.indonesia.memprihatinkan

http://www.maarif-nu.or.id/Warta/tabid/156/ID/2223/Rapat-PlenoPengurus-Pusat-LP-Maarif-NU-Hasilkan-9-Prioritas-Programdi-2014.aspx 
Nur Hidayah

halaman ini bukan sengaja dikosongkan 